III. - UTILISATION DIGESTIVE DES NUTRIMENTS.

METABOLISME ET INFLUENCE DES FACTEURS DE VARIATION

DIGESTIBILITY OF NUTRIENTS.

METABOLISM AND EFFECT OF SOME VARIATION FACTORS

\title{
ESSAI D'UTILISATION DES SYSTÈMES COMPARTIMENTÉS DANS UNe ÉTUde SUR LA PHYSIOLOGIE de LA DIGESTION
}

\author{
R. TOMASSONE et J.-P. LAPLACE \\ Laboratoire de Biométrie, \\ * Laboratoire de Physiologie de la Nutrition, \\ Centre national de Recherches zootechniques, I. N.R. A., \\ 78350 Jouy en Josas
}

1. - Vers une interprétation physique des mécanismes d'un système

Les analyses statistiques appliquées dans les études de la physiologie de la digestion ne débordent en général pas du cadre relativement strict de la " statistique classique " : calcul de moyennes et de variances, analyses de variance. Les études les plus dynamiques font appel à la régression. Mais, si on peut définir les intervalles de variation, des limites de confiance, on a tout de même l'impression générale que l'outil statistique ne s'intègre pas totalement aux données expérimentales. Ces outils décrivent les phénomènes, mais ils ne fournissent que très rarement une aide à l'étude de leur évolution. Il existe une branche d'investigation particulièrement bien adaptéc à l'étude des problèmes de dynamique des phénomènes biologiques : celle des modèles à compartiments.

L'origine de ces techniques remonte aux premières utilisations d'isotopes radioactifs comme traceurs. A l'origine, l'étude de ces traceurs fut très qualitative; puis, dès que le concept de compartiment fut introduit, l'utilisation d'équations différentielles pour décrire les phénomènes permit une approche beaucoup plus fine : la représentation d'un système par un système d'équations différentielles a l'avantage de permettre une interprétation physique du mécanisme du système global. C'est elle qui explique la grande puissance de ces méthodes qui peuvent permettre :

- de retrouver la dynamique d'un élément,

- de connaître les quantités mises en jeu lors de transformations inobservables,

- de mettre en évidence des mécanismes de régulation.

\section{2. - Terminologie des modèles compartimentés}

Sans entrer dans une étude complète de la terminologie, il est indispensable de définir quelques termes que nous emploierons constamment :

- un système est n'importe quel système biochimique ou physiologique à l'intérieur duquel on veut étudier l'évolution d'une substance, et sur lequel on peut faire des expériences. Il peut 
être fermé, dans le cas où on ne peut admettre aucun échange avec l'extérieur, et ouvert si des échanges sont possibles avec l'environnement.

- un compartiment est un sous-ensemble d'objets du système, dans lequel l'élément étudié possède une cinétique uniforme mais que l'on peut distinguer de celle d'autres objets du système. C'est une classe d'équivalence de l'élément étudié.

- un modèle théorique est une représentation de la cinétique de l'élément étudié dans le système.

- un modèle mathématique est un ensemble d'équations dérivées du modèle théorique, qui décrivent les concentrations ou les quantités de la substance en fonction du temps. Par exemple, la cinétique du phosphate non-organique dans un animal peut être représentée par le modèle théorique suivant :

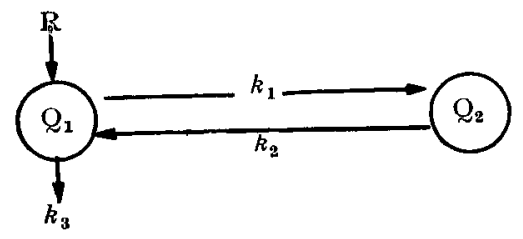

Si $Q_{1}$ et $Q_{2}$ sont les quantités de phosphate dans les deux compartiments, $R$ ce qui entre dans le premier : si nous supposons que ce qui sort du compartiment est proportionnel à la concentration de ce compartiment, le modèle mathématique correspondant à ce modèle théorique est :

$$
\begin{aligned}
& \frac{d Q_{1}}{d t}=\mathrm{R}-k_{1} Q_{1}+k_{2} Q_{2}-k_{3} Q_{1} \\
& \frac{d Q_{2}}{d t}=k_{1} Q_{1}-k_{2} Q_{2}
\end{aligned}
$$

L'intégration de ce système d'équations différentielles permet de déterminer les équations $Q_{1}(t)$ et $\mathrm{Q}_{2}(t)$ à partir du moment où sont connues les conditions initiales.

\section{3. - Traitement des données expérimentales : ajustement}

Pour les modèles à compartiments usuels, les modèles mathématiques à ajuster sont les solutions du système d'équations différentielles précédent ; ils sont de la forme :

$$
\mathrm{Q}_{\ell}(t)=\sum_{j=l}^{j=n} a_{i j} e^{-\lambda} j t \quad i=\mathrm{r}, 2 \ldots n
$$

où $n$ est le nombre de compartiments; les $\lambda_{j}$, coefficients du temps dans les exponentielles sont les mêmes pour chaque compartiment; seuls les coefficients $a_{i j}$ diffèrent d'un compartiment à l'autre. Deux possibilités existent pour calculer ces coefficients :

- utiliser des calculateurs analogiques qui permettent à partir du moment où le programme est fait, de réaliser en même temps l'ajustement et la simulation du phénomène ; la forme

- utiliser des calculateurs numériques qui permettent de rendre minimum des quantités de

$$
\mathrm{U}(\underline{Q}, \underline{t} ; \underline{a}, \underline{\lambda})=\sum_{k=1 ; i=1}^{m, n}\left(Q_{i}\left(t_{k}\right)-\sum_{j=1}^{j=n} a_{i j} \mathrm{e}^{-\lambda} j t k\right)^{2}
$$

$k=\mathbf{I}, 2 \ldots m$ représente le nombre d'observations des variables $Q_{i}$, plus précisément $Q_{i}\left(t_{k}\right)$ est la quantité de la substance dans le compartiment $i$ au temps $t_{k}$. Les techniques de minimisation permettent de calculer l'ensemble des paramètres $a$ et $\underline{\underline{\lambda}}$ après avoir observé $\underline{Q}$ aux différents temps $\underline{t}$; ces techniques ont l'avantage de fournir une estimation numérique des paramètres 
ainsi qu'une estimation de leurs variances et covariances. Malheureusement les problèmes numériques ne sont pas très simples : deux termes qui font intervenir des exponentielles $\mathrm{e}^{-\lambda} j$ et $\mathrm{e}^{-\lambda} j$ ne sont numériquement séparés que si $\lambda_{j}$ et $\lambda_{j}$ sont bien différents ; trop voisins ils ne pourront être représentés que par un seul terme.

\section{4. - Utilisation : simulation et identification de systèmes}

Quand les valeurs des constantes d'ajustement sont connues, on peut naturellement utiliser les équations pour simuler le modèle ; et c'est sûrement un des aspects les plus séduisants de cette technique. On peut par exemple se demander comment de petites modifications d'un des compartiments du système peut modifier la cinétique de l'ensemble. Quelquefois on se trouve en présence de plusieurs modèles théoriques possibles; ainsi dans une expérience sur le métabolisme du glucose chez le rat (BAKER et al.), trois modèles théoriques étaient possibles, chacun à trois compartiments ; les modèles mathématiques une fois formulés et les paramètres estimés, on a pu dire que le modèle $\mathrm{C}$ était le plus plausible.
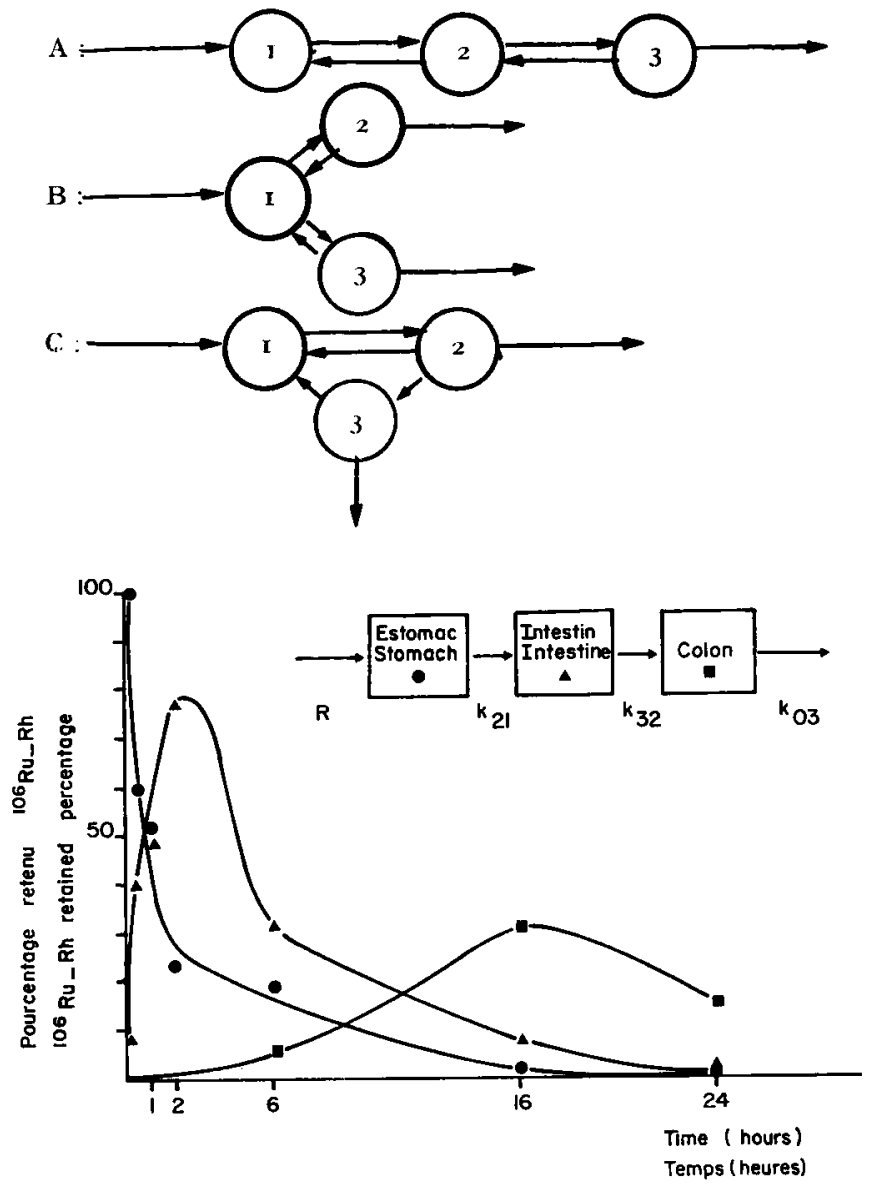

FIG. I. - Représentation graphique de l'évolution simultanée au cours du temps du pourcentage de la dose de 106 Ru-Rh, présent dans chacun des trois compartiments

(sur la base des données numériques de Sikov et al., I969, chez le rat)

FIG. I. - Graphical representation of the simultaneous variation during time of the percentage of the dose of $106 \mathrm{Ru}-\mathrm{Rh}$, in each of the three compartments (from numerical data of Sikov and al., 1969, in the rat) 


\section{5. - Exemple d'application}

Nous avons repris l'exemple cité par Sikov et al. (1969) (fig. I) ; nous l'avons considéré comme un modèle à trois compartiments : estomac, intestin et côlon. De plus nous avons encore simplifié le modele theorique en supposant que tout ce qui arrive dans un "compartiment "provient de celui qui le précède. Sous cette hypothèse le modèle général se simplifie: de I 2 coefficients à déterminer (les $9 a_{i j}$ et les $3 \lambda_{j}$ ) on passe à 9

$$
\begin{aligned}
& Q_{1}=\mathrm{X}_{1} \mathrm{e}^{-\lambda l t} \\
& Q_{2}=\mathrm{X}_{2} \mathrm{e}^{-\lambda l t}+\mathrm{X}_{3} \mathrm{e}^{-\lambda_{2} t} \\
& Q_{3}=\mathrm{X}_{4} \mathrm{e}^{-\lambda l t}+\mathrm{X}_{5} \mathrm{e}^{-\lambda_{2} t}+\mathrm{X}_{6} \mathrm{e}^{-\lambda_{3} t}
\end{aligned}
$$

et même à 6 en tenant compte des conditions initiales à l'instant $t=0$, puisque tout étant alors concentré dans l'estomac $Q_{1}=$ Ioo, et l'intestin et le côlon sont vides $Q_{2}=Q_{3}=0$, c'est-à-dire $\mathrm{X}_{2}+\mathrm{X}_{3}=\mathrm{o}$ et $\mathrm{X}_{4}+\mathrm{X}_{5}+\mathrm{X}_{6}=\mathrm{o}$ (afin de simplifier les notations les $\mathrm{X}$ correspondent aux $a_{i j}$ du texte). Le simple examen des courbes obtenues après ajustement montre combien le modèle choisi est sûrement voisin de la réalité ; aucun type d'ajustement " classique " n'aurait permis une aussi bonne modélisation.

\section{RÉFÉRENCES BIBLIOGRAPHIQUES}

Les références sur l'étude des modèles compartimentés sont abondantes; nous nous limitons ici à celles qui nous ont aidé à bâtir ce texte. On pourra trouver de nombreuses applications dans des revues médicales.

Atkins G. L., I969. Multicompartment models for biological Systems, Methuen and Co, London, I54 p.

Baker N., Shipley R. A., Clark R. E., Incepy G. E., I959. C14 studies in carbohydrate metabolism : glucose pool size and rate of turnover in the normal rat. Am. J. Physiol., r96-245.

Hammer P. C., I969. Advances in mathematical systems theory. Penn. State Univ. Press, London, I74 p.

Matis J. H., Hartley H. O., 1970. Stochastic compartmental analysis : model and least squares estimation from time series data. Congrès Int. Biométrie. Karlsruhe, $29 \mathrm{p}$.

Richalet J. et al., r97o. Étude et identification des systèmes compartimentés. Document Ec. Nat. Sup. Aeronautique, Centre d'Études et de Recherches en automatisme, Velizy-Villacoublay.

Savoie J. C., Massin J. P., Vallee G., I97o. Cinétique de l'iodure chez l'homme. Analyse par ordinateur et modèle tricompartimental. I. Application à l'athyroïdie et au goître simple. II. Application aux anomalies de l'hormogenese thyroïdienne avec test au perchlorate positif. Ann. Endocrinologie, 31, 688-699.

SchneIder B., 1969. Mathematical and statistical problems in pharmacokinetics. Advances in the Biosciences, 5 .

Sikov M. R., Thomas J. M., Mahlum D. D., I969. Comparison of passage of a tracer through the gastrointestinal tract of neonatal and adult rats. Growth, 33, 57-68.

WiSE M. E., 1970. The evidence against compartments. Congrès Int. Biométrie, Karlsruhe, 2 p.

\section{SUMMARY}

UTILIZATION OF COMPARTMENT SYSTEMS

\section{FOR STUDYING THE PHYSIOLOGY OF DIGESTION}

\section{1. -- Physical interpretation of the mechanisms of a system}

The statistical analyses used to study physiology of digestion generally belong to the field of "classical statistics ": calculation of means and variances, analysis of variance. The most dynamic studies make use of the regression. However, even though it is possible to define the inter- 
vals of variation and confidence limits, the general impression is that the statistical tool is not totally adapted to the experimental data. These tools describe the phenomena, but they only seldomly contribute to determine their variation. An investigation method particularly well adapted to the study of the problems concerning dynamics of biological phenomena is that of the multicompartment models.

These techniques have been developed when radioactive isotopes were used for the first time as tracers. Initially, the study of these tracers was very qualitative, but when the concept of compartments was introduced, the utilization of differential equations to describe the phenomena resulted in a much more accurate approach : the description of a system by differential equations has the advantage of allowing a physical interpretation of the mechanism of the total system. This interpretation accounts for the great value of these methods by means of which it is possible :

- to recover the dynamics of an element,

- to know the quantities involved in the case of unobservable transformations,

- to demonstrate evidence of regulatory mechanisms.

\section{2. - Terminology of multicompartment models}

Without entering into details let us however define some of the terms that we are going to use constantly :

- a system represents any biochemical or physiological system within which one intend to study the variation pattern of a substance and on which one may carry out experiments. It can be closed, in the case where no exchange with the outside is admitted, and open if exchanges with the environment are possible.

- a compartment is a sub-set of objects in the system, in which the studied element has an uniform kinetic which can be distinguished from that of other objects of the system. It is a class of equivalence of the element studied.

- a theoretical model is a representation of the kinetic of the element studied in the system ;

- a mathematical model is a series of equations derived from the theoretical model, which describe the concentrations or quantities of the substance according to time. The kinetic of inorganic phosphate in an animal for instance, can be represented by the following theoretical model :

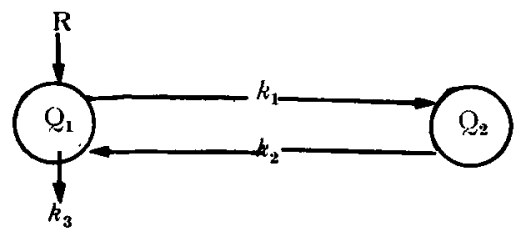

If $Q_{1}$ and $Q_{2}$ are the amounts of phosphate in the two compartments, $R$ the amount entering the first one, and if we suppose that the amount which leaves the compartment is proportional to the concentration of the latter, the mathematical model corresponding to this theoretical model is the following :

$$
\begin{aligned}
& \frac{\mathrm{d} Q_{1}}{\mathrm{~d} t}=\mathrm{R}-k_{1} Q_{1}+k_{2} Q_{2}-k_{3} Q_{1} \\
& \frac{\mathrm{d} Q_{2}}{\mathrm{~d} t}=k_{1} Q_{1}-k_{2} Q_{2}
\end{aligned}
$$

The integration of this system of differential equations allows to determine the equations $Q_{1}(t)$ and $Q_{2}(t)$ from the moment when the initial conditions are known. 


\section{3. - Treatment of experimental data: fitting}

For the models with usual compartments, the mathematical models to be fitted are the solutions of the previous system of differential equations. These models are as follows :

$$
\mathrm{Q}_{i}(t)=\sum_{j=l}^{j=n} a_{i j} \mathrm{e}^{-\lambda_{j} t} \quad i=\mathrm{I}, 2 \ldots n
$$

where $n$ is the number of compartments; the $\lambda_{1}$, time coefficients in the exponentials are the same for each compartment ; only the $a_{i j}$ differ from one compartment to another. These coefficients can be calculated in two manners :

- utilization of analogue computers by means of which it is possible, from the moment when the program is made, to carry out simultaneously the fitting and simulation of the phenomenon.

- utilization of digital computers allowing reduction to a minimum of the quantities of the type.

$$
\mathrm{U}(\underline{Q}, \underline{t} ; \underline{a}, \lambda)=\sum_{k=l ; l=l}^{m=n}\left(Q_{1}\left(t_{k}\right)-\sum_{j=l}^{j=n} a_{i j} \mathrm{e}^{-\lambda} j t_{k}\right)_{2}
$$

$k=\mathbf{I}, 2 \ldots m$ represents the number of observations of the variables $Q_{1}$, more accurately $Q_{1}\left(t_{k}\right)$ is the quality of the substance in compartment $i$ at the time $t_{k}$. Minimization techniques allow to calculate all parameters $a$ and $\underline{\lambda}$ after having observed $\underline{Q}$ at different times $t$. These techniques have the advantage of supplying a numerical estimation of the parameters as well as an estimation of their variances and covariances. Unfortunately the numerical problems are not very simple : two terms which make exponentials $e^{-\lambda} j$ and $e^{-\lambda} j$ intervene, are only numerically separated when $\lambda_{f}$ and $\lambda_{j}$ are very different; if they are too similar they can only be represented by one only term.

\section{4. - Utilization : simulation and identification of systems}

When the values of the fitting constants are known, it is naturally possible to usc the equations to simulate the model ; and this is obviously one of the most attractive aspects of this technique. One may for instance wonder how some small changes of one of the compartments of the system can modify the kinetic of the whole system. Sometimes several theoretical models are available. Thus, in an experiment on glusose metabolism in the rat (BAKER and al.) three theoretical models could be used, each one with three comparments. Once the mathematical models formu1 ated and the parameters estimated, model $\mathrm{C}$ was found to be the most plausible one.

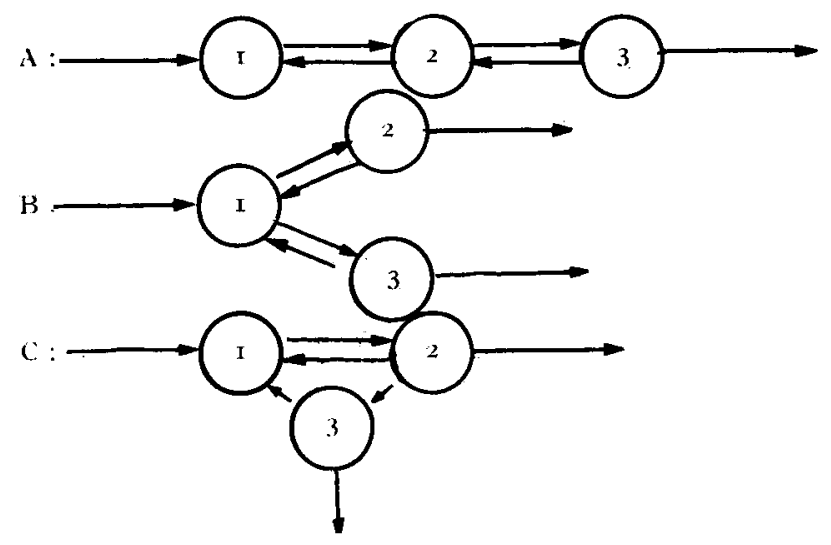




\title{
5. - Example of application
}

We have taken the example reported by Sikov and al. (1969); we considered it as a model of 3 compartments : stomach, intestine and colon. In addition, we simplified the theoretical model even more by supposing that all that enters a "compartment " proceedes from the previous one. With this hypothesis, the general model is simplified : from 12 coefficients to be determined (the $9 a_{i j}$ and the $3 \lambda_{j}$ ) only 9 are used.

$$
\begin{aligned}
& Q_{1}=\mathrm{X}_{1} \mathrm{e}^{-\lambda l t} \\
& Q_{2}=\mathrm{X}_{2} \mathrm{e}^{-\lambda l t}+\mathrm{X}_{3} \mathrm{e}^{-\lambda_{2} t} \\
& Q_{3}=\mathrm{X}_{4} \mathrm{e}^{-\lambda l t}+\mathrm{X}_{5} \mathrm{e}^{-\lambda_{2} t}+\mathrm{X}_{6} \mathrm{e}^{-\lambda_{3}} 3^{t}
\end{aligned}
$$

and even 6 , considering the initial conditions at the moment $t=0$, since all is then concentrated in the stomach $Q_{2}=100$, and the intestine and colon are empty $Q_{2}=Q_{3}=0$, that is $\mathrm{X}_{2}+\mathrm{X}_{3}=\mathrm{o}$ and $\mathrm{X}_{4}+\mathrm{X}_{5}+\mathrm{X}_{6}=\mathrm{o}$ (in order to simplify the notations, the $\mathrm{X}$ correspond to the $a_{i f}$ in the text). More examination of the curves obtained after fitting shows to which extent the chosen model is close to reality; no "classical " type of fitting would have allowed such a good modelization.

\section{ACTION DE L'AUROTHIOGLUCOSE SUR LA GLYCÉMIE DU MOUTON}

\author{
V. BABAPOUR et J. BOST \\ Laboratoire de Physiologie et Pharmacodynamie, \\ École nationale vétérinaire de Lyon, I. N. R. A., \\ 2, quai Chauveau \\ 69337 Lyon Cedex 1
}

De nombreux arguments expérimentaux tendent à démontrer que la prise de nourriture, chez les ruminants, n'est pas réglée par un mécanisme glycostatique. Les modifications de la glycémie (insuline, glucose), en particulier, n'induisent pas de variation appréciable de l'ingestion alimentaire.

Houpt et HANCE (1969) ont cependant constaté chez la chèvre que des perfusions de 2-désoxyD-glucose $(\mathrm{r}-3 \mathrm{mg} / \mathrm{kg} / \mathrm{mn})$ pouvaient augmenter la prise de nourriture. Ce résultat suggère l'existence de gluco-récepteurs chez cette espèce. Bien au contraire, BAILE, MAYER et al. (1970), injectant par voie intra-carotidienne de fortes doses d'aurothioglucose $(2 \mathrm{mg} / \mathrm{kg})$ à des chèvres et à des moutons n'ont obtenu ni lésion hypothalamique ni hyperphagie après trois semaines de survie. La concentration d'or dans le sang veineux était cependant 20 à 40 fois supérieure à celle qui détermine chez la souris les lésions classiques des noyaux ventro-médiaux et l'hyperphagie. Plus récemment, SEoane et BaILe (1972) ont constaté que l'injection de solutions de 2-désoxy$\mathrm{D}$-glucose dans le $3^{\mathrm{e}}$ ventricule du mouton déclenche une augmentation rapide de la prise alimentaire mais des résultats identiques sont obtenus avec le xylose et la réponse semble en rapport avec l'hyperosmolarité du liquide céphalo-rachidien.

L'échec des essais réalisés avec l'aurothioglucose peut éventuellement dépendre des parti- 